\title{
THE MECHANISM OF ACTION OF COWPER'S SECRETION IN COAGULATING RAT SEMEN
}

\author{
R. G. HART \\ Department of Biological Science, Slippery Rock State College, \\ Slippery Rock, Pennsylvania
}

(Received 14th May 1968)

In the rat, mouse and hamster, but not in the guinea-pig, Cowper's secretion reacts in vitro with vesicular secretion to produce a coagulant (Hart \& Greenstein, 1968). Unlike vesiculase, the $\mathrm{pH}$ optimum of this reaction is acidic. In the rat, the active agent secreted by Cowper's glands that is responsible for coagulation is heat stable and non-dialysable. Electrophoretically the active molecule migrates only slightly at a $\mathrm{pH} 8.6$ and reacts chemically as a glycoprotein.

The vesicular substrate in the rat which coagulates upon exposure to Cowper's secretion has been shown to be a protein, electrophoretically different from the substrate of vesiculase (Hart \& Greenstein, 1968). Recent data suggest that vesiculase promotes vesicular coagulation by transamidase reactions (Notides \& Williams-Ashman, 1967). This paper presents evidence which suggests that the mechanism by which Cowper's secretion coagulates vesicular substrate is non-enzymatic, involving, at least in part, an ionic interaction between Cowper's secretion and substrate.

Cowper's secretion was obtained from mature male rats by milking the glands into a phosphate buffered solution of $\mathrm{pH} 5.9$ which contained $10 \%$ $(\mathrm{w} / \mathrm{v})$ ammonium sulphate. The solution was dialysed for $12 \mathrm{hr}$ at $4^{\circ} \mathrm{C}$ against a $10 \%(\mathrm{w} / \mathrm{v})$ ammonium sulphate solution, $\mathrm{pH} 5.9$. The non-dialysable material was then dialysed for $24 \mathrm{hr}$ at $4^{\circ} \mathrm{C}$ against several changes of phosphate buffer, $\mathrm{pH} 5.9$ and centrifuged for $20 \mathrm{~min}$ at $4000 \mathrm{rev} / \mathrm{min}$. The clarified supernatant of Cowper's secretion was subsequently used in studying semen coagulation. Seminal vesicle secretion was prepared as described previously (Hart \& Greenstein, 1968). Protein concentration was determined spectrophotometrically (Fruton \& Simmonds, 1958) and the coagulation reaction was followed photometrically at $660 \mathrm{~m} \mu$ at room temperature (Gotterer, Ginsberg, Schulman, Banks \& Williams-Ashman, 1955).

Varying concentrations of vesicular substrate were reacted in vitro with a constant amount of Cowper's secretion (Text-fig. 1). Regardless of the concentration of vesicular secretion used, the maximum amount of coagulation produced in each case was nearly identical. Moreover, the time required for maximum coagulation to occur did not vary as the substrate concentration increased. At $40 \mathrm{~min}$ after the initial coagulation reaction was complete, an identical concentration of Cowper's secretion $(0.12 \mathrm{mg}$ protein) was added to 
each reaction tube (Text-fig. 1). In all cases, a new reaction began but, unlike the initial reaction, substrate concentration was limiting in the cases of low protein concentration and thus reduced the maximum amount of coagulation obtained. Thus, at non-limiting substrate concentrations, the amount of coagulant produced depended directly upon the concentration of Cowper's secretion.

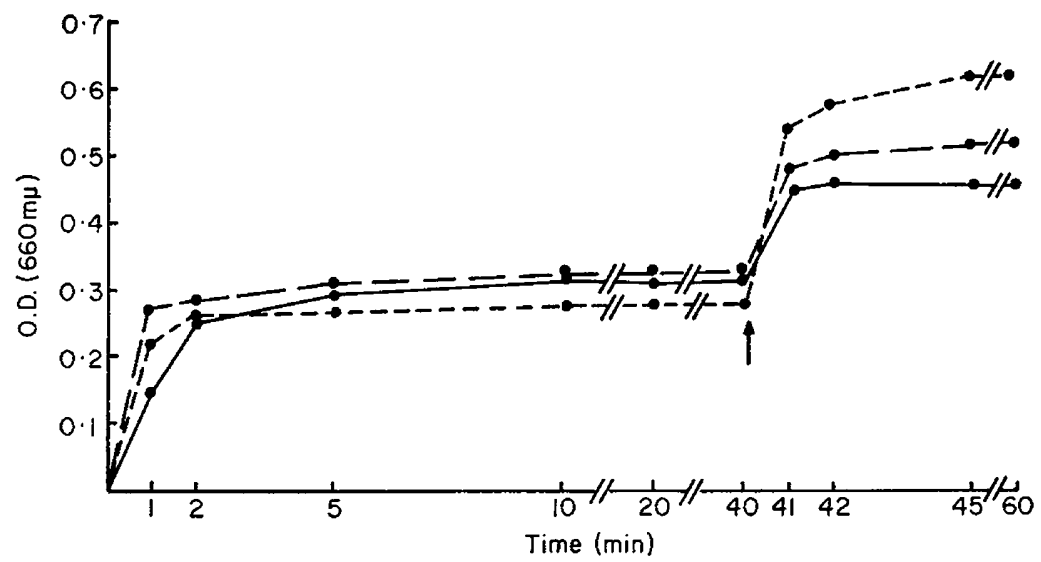

Text-Fig. 1. The effect of substrate concentration on vesicular coagulation. The value next to each line represents the $\mathrm{mg}$ of vesicular protein per reaction tube. All tubes contained $0.12 \mathrm{mg}$ of Cowper's secretion protein in a total volume of $4 \mathrm{ml}$ (phosphate buffer, $\mathrm{pH} 5 \cdot 9$ ). The arrow indicates the point in the reaction where a second addition of Cowper's secretion $(0.12 \mathrm{mg}$ protein) was made.,$- 0.06 \mathrm{mg} ;----, 0.12 \mathrm{mg}$; - - , $0.18 \mathrm{mg}$.

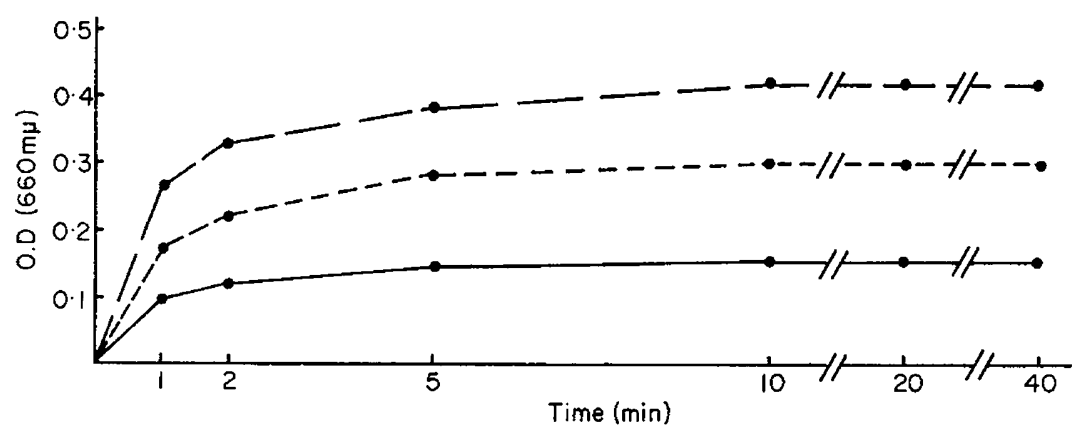

Texr-frc. 2. The effect of Cowper's secretion concentration on vesicular coagulation. The value next to each line represents the mg of Cowper's secretion protein per reaction tube. All tubes contained $2.6 \mathrm{mg}$ of vesicular protein in a total volume of $4 \mathrm{ml}$ (phosphate buffer, $\mathrm{pH} 5 \cdot 9$ ). -, $2.6 \mathrm{mg} ;-\longrightarrow, 5.2 \mathrm{mg} ; . . . ., 7.8 \mathrm{mg}$.

Text-fig. 2 shows that there was a marked positive relationship between the amount of Cowper's secretion added to vesicular substrate and the percentage increase in the reaction maximum. These results are distinctly different from those reported for vesiculase (Gotterer et al., 1955). In their report, varying the concentration of vesiculase in a reaction mixture affected only the time required for the reaction to reach maximum. The amount of coagulant obtained did not vary with enzyme concentration. 
The effect of ionic strength on the coagulatory reaction is shown in Table 1. Concentrations of $\mathrm{NaCl}$ between 180 and $200 \mu$ moles/ml almost completely abolished coagulation. Decreasing the concentration of $\mathrm{NaCl}$ below 180 $\mu \mathrm{moles} / \mathrm{ml}$ correspondingly increased the amount of coagulant obtained. However, at concentrations of $\mathrm{NaCl}$ which allowed the reaction to proceed, the time required for each reaction to reach maximum was constant and identical to the reactions illustrated in Text-fig. 1. In the case of vesiculase, ionic strength influences only the time required for the reaction to reach maximum (Gotterer et al., 1955). Like vesiculase, however, Versene effectively abolished the coagulation reaction involving Cowper's secretion (Table 1). $p$-Chloromercuribenzoic acid at concentrations of 60 or $100 \mu \mathrm{moles} / \mathrm{ml}$ had no effect on the ability of Cowper's secretion to coagulate vesicular protein (Table 1).

TABLE 1

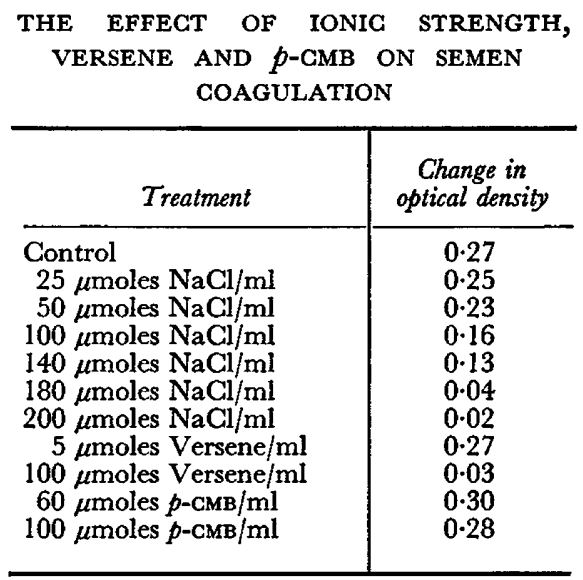

All reactions were carried out in a total
volume of $4 \mathrm{ml}$ (phosphate buffer, $\mathrm{pH} 5 \cdot 9$ )
which contained $8 \mathrm{mg}$ vesicular protein and
$0.12 \mathrm{mg}$ of Cowper's secretion protein. The
optical density values recorded represent the
final reading made 120 min after the reactions
were initiated. The control reaction lacked
$\mathrm{NaCl} p$-Chloromercuribenzoic acid $=p$-cMB.

These data indicate that the in vitro interaction of Cowper's and vesicular secretion to produce a coagulant proceeds by a non-enzymatic mechanism. The effect of ionic strength on the reaction would suggest that ionic interactions are involved in coagulation. The inhibitory effect of Versene demonstrates the involvement of metal ions in the reaction, while the failure of $p$-chloromercuribenzoic acid to affect coagulation would suggest that active sulphydryl groups are not involved in the interaction (Rosemeyer \& Huehns, 1967).

Despite the fact that the data presented suggest that the coagulatory mechanism of Cowper's secretion is non-enzymatic, this by no means implies the reaction lacks specificity. Cowper's secretion in the rat coagulates a specific protein fraction of vesicular secretion, but displays a sharp reduction in activity when reacted with guinea-pig vesicular secretion (Hart \& Greenstein, 1968). 
This work has been supported by a grant from the Society of the Sigma Xi.

\section{REFERENCES}

Fruton, J. S. \& Simmonds, S. (1958) General biochemistry, 2nd edn, p. 74. John Wiley, New York.

Gotterer, G., Ginsberg, D., Schulman, T., Banks, J. \& Williams-Ashman, H. G. (1955) Enzymatic coagulation of semen. Nature, Lond. 176, 1209.

Hart, R, G. \& Greenstein, J. S. (1968) A newly discovered role for Cowper's gland secretion in rodent semen coagulation. J. Reprod. Fert. 17, 87.

Notides, A. C. \& Williams-Ashman, H. G. (1967) The basic protein responsible for clotting of guineapig semen. Proc. natn. Acad. Sci. U.S.A. 58, 1991.

Rosemeyer, M. A. \& Huehns, E. R. (1967) On the mechanism of the dissociation of haemoglobin. 7. molec. Biol. 25, 253. 